\title{
Planning of Waste Management Systems in Urban Area Using Multi-criteria Analysis
}

\author{
Agnieszka Generowicz $^{1}$, Zygmunt Kowalski ${ }^{2}$, Joanna Kulczycka ${ }^{3}$ \\ ${ }^{1}$ Institute of Water Supply and Environmental Protection, Cracow University of Technology, Cracow, Poland; ${ }^{2}$ Institute of Chemistry \\ and Inorganic Technology, Cracow University of Technology, Cracow, Poland; ${ }^{3}$ Mineral and Energy Economy Research Institute, \\ Polish Academy of Sciences, Cracow, Poland. \\ Email: agenerowicz@pk.edu.pl,zkow@chemia.pk.edu.pl,kulczycka@meeri.pl
}

Received March 30 ${ }^{\text {th }}, 2011$; revised May $8^{\text {th }}, 2011$; accepted June $17^{\text {th }}, 2011$.

\begin{abstract}
Planning of waste management system in urban area should take into consideration many legal, technological, financial, economic, technical, ecological, social and spatial aspects. The aim of the paper is to propose the method, which can be helpful in planning procedure of waste management system in European cities or regions, which comprise with following steps: identification of produced volume and municipal solid waste characteristics in the region for providing grounds to design a technological system, identification of other financial, economic, legal, social aspects for creation of waste management scenarios, definition of the criteria allowing evaluate designed waste management scenarios based on plan requirements, make an the multi-criteria analysis for choosing the best scenario in the region. Such analyses were conducted to evaluate the proposed different waste management systems in city of Cracow in 2000, 2004 and 2007. This comparison of theses systems shows that evaluating criteria were tightened as a result of toughening regulations of both Polish and the EU laws.
\end{abstract}

Keywords: Municipal Waste, Urban Area, Planning, Multi-criteria Analysis, Waste Management System

\section{Introduction: Waste Management System as a Base for Planning}

In Poland, waste management plans worked out on the national, provincial, county and district levels are one of the most important instruments supporting the realization of correct actions regarding waste management. The Act on Waste [1] sets out the form and scope of these plans, however the scope is very general. These plans can be a tool for setting targets at national and local level, and present challenges to local authorities and to plan necessary facilities. However, to achieve sustainable waste management the complex system should be implemented for every urban area. The complex waste management system should allow achieve many inconsistent goals: technical, legal, economic, ecological, spatial, and social. Planning and selection of waste management system structure is a multi-stage process involving identification of differences and common elements of variant solutions, selection the most favourable solution, and evaluation of operation results [2-6].

Planning scenarios of waste management system in the urban area should be developed on the basis of existing legal articles and local determinants, which determine quality of generated waste stream and its size [3,5]. Waste characteristics provide grounds to design a technological system with more or less complex structure, which has to ensure safe for environment proceeding with all waste generated in the region $[4,7]$. The next stage is to find criteria allowing evaluate designed technological system. These criteria should comprehensively assess the functioning of a complex waste management system. Taking into account the principles of sustainable development, the following groups of criteria have been proposed $[2,8]$ :

- Technical determining e.g. the degree of waste stream reduction resulting from the system functioning, operation time of landfill site for final wastes, reduction in mass of biodegradable wastes, the volume of secondary materials recovered as a result of the system functioning, energy recovery level, etc.

- Ecological e.g. emissions from individual waste management system installations, emissions from means of transport, the impact of complex waste management system on natural environment, environmental benefits resulting from waste stream reduction, emis- 
sion reduction, etc.

- Economic taking into account investment outlays and the system operating costs, and possible economic profits arising from the system functioning, e.g. profits from the sale of secondary materials.

- Social most difficult to use in measurable assessment, which may take into account the following: approval of system solution or individual technologies, possibility to create new jobs, approval of the impact of waste processing technologies on environment, but also political criteria, compliance with directions indicated by legal articles and waste management plans, etc.

- Spatial/regional in urban area the shortage of land for waste facilities (landfills, incinerations) is a significant problem, strengthening the NIMBY effect.

- Legal/political according to strategy for the Malopolska region the aim is to reduce the volume of waste produced and to introduce of a system of waste recycling and disposal, compatible with European standards [9].

Acceptance and calculation of individual criteria are dependent on numerous factors and specificity of the city, in which the system is expected to function. Description of system functions should cover all criteria. Due to the fact that not all of them are measurable and easy to compute, some may be omitted in computational process. In order to make computations easier, it is also possible to combine individual groups of criteria, e.g. technical and ecological [10-12].

\section{Waste Management Systems in Cracow City Scenarios Analysis}

The total amount of municipal solid waste generated in Cracow city was about $327,000 \mathrm{Mg}$ in 2007 . Waste is generally collected through "one-container system", with variable capacity of containers and mainly (86\%) disposed on landfills (Barycz landfill in Cracow), about 4\% is composted and 10\% separate collected, i.e. in 2007 there were 550 recycling banks, which allowed to collect $4537 \mathrm{Mg}$ of metal, paper, PET bottles, and glass. Cracow also plans to construct with the help of EU-fund a 240,000 $\mathrm{Mg}$ per year an incinerator plant, but as the protest of local citizen was very strong, therefore many variants for localisation have been taken into account. The introduction of new solutions in waste management system in Cracow was necessary to be in accordance with Polish and EU legal requirements and tasks indicated in waste management plans. In 2007 in Cracow waste management procedures were carried out according to the entries in Municipal Waste Management Plan [13].

- Continuation of current state model based on existing infrastructure. When implementing scenario S0, it will be required to extend the waste management system by adding another landfill site not later than in years 2017-2018. However, this scenario will not meet requirements specified in the Law on Waste $[1,14]$ regarding reduction in mass of biodegradable municipal waste sent for dumping after 2013.

- Extension of sorting lines and adding new composting plant modules. When implementing scenario S1, it will be required to build another waste sorting and composting installations, mechanical and biological unit for processing not segregated (mixed) municipal waste, and landfill site in years 2017-2018. Additionally, implementation of scenario S1 will require considerable financial outlays for ecological education and developing segregation "at the source". The scenario will also require construction of another landfill site for final waste.

- Extension of sorting lines and adding new composting plant modules. When implementing scenario S2, it will be required to extend waste management system by adding another waste sorting and composting installations, mechanical and biological unit for processing not segregated (mixed) municipal waste(and since 2016 also collected selectively), and to build landfill site in years 2018-2019. Additionally, implementation of scenario S2 will require considerable financial outlays for ecological education and developing segregation "at the source". Functioning of this scenario will also require adding landfill site for final waste.

- Taking into account thermal processing of waste, as the system element. Implementation of scenario S3 will require first of all financial outlays for building thermal processing plant for waste.

The scenarios are presented in Table 1. For evaluation of these scenarios, three groups of criteria, which describe the system, are shown in Tables 2 and 3.

\section{Multi-criteria Analysis as the Method Used to Compare Scenarios of Waste Management Systems}

Multi-criteria analysis was proposed to compare these scenarios using proposed 11 criteria [11,12,15-19]. Compromise programming method using the concept of arranging/ordering individual strategies according to their distance from predetermined ideal point $\mathrm{X}^{\prime}$ ( $\mathrm{x} 1$ ', $\mathrm{x} 2$ ', ..., xM') was employed to solve the decision-making task. Coordinates of ideal point xM' are the most favourable values of criteria. Mathematical notation of the method is an equation defining criterion value, which aggregates the measure of distance between examined strategy and ideal point: 
Table 1. Technical description of waste scenarios for the city of Cracow in 2007.

\begin{tabular}{|c|c|c|c|c|}
\hline Elements system & $\begin{array}{l}\text { So - continuation of current } \\
\text { state-model based on } \\
\text { existing infrastructure }\end{array}$ & $\begin{array}{l}\text { S1-extension of sorting } \\
\text { lines and adding new } \\
\text { composting plant modules }\end{array}$ & $\begin{array}{l}\text { S2 - extension of sorting } \\
\text { lines and adding new } \\
\text { composting plant modules }\end{array}$ & $\begin{array}{l}\text { S3 - taking into account } \\
\text { thermal processing of waste, } \\
\text { as the system element }\end{array}$ \\
\hline $\begin{array}{l}\text { Composting plant for } \\
\text { green waste }\end{array}$ & \multicolumn{4}{|c|}{ Two installations, each processing green waste amounting to $6000 \mathrm{Mg} / \mathrm{year}$} \\
\hline $\begin{array}{l}\text { Composting plant for } \\
\text { wet fraction }\end{array}$ & - & $\begin{array}{l}\text { Two-container system with } \\
\text { output of } 45,000 \mathrm{Mg} / \text { year }\end{array}$ & $\begin{array}{l}\text { Two-container system with } \\
\text { output of } 65,000 \mathrm{Mg} / \text { year }\end{array}$ & $\begin{array}{l}\text { Two-container system with } \\
\text { output of } 12,000 \mathrm{Mg} / \text { year }\end{array}$ \\
\hline Sorting plant & $8000 \mathrm{Mg} /$ year & $\begin{array}{l}16,000 \mathrm{Mg} / \text { year, } \\
20,000 \mathrm{Mg} / \text { year }\end{array}$ & $\begin{array}{l}16,000 \mathrm{Mg} / \text { year, } \\
25,000 \mathrm{Mg} / \text { year }\end{array}$ & $16,000 \mathrm{Mg} /$ year, \\
\hline $\begin{array}{l}\text { Mechanical and } \\
\text { biological processing }\end{array}$ & \multicolumn{4}{|c|}{$\begin{array}{l}\text { For mixed waste (not segregated) municipal waste with out- } \\
\text { put of } 120,000 \mathrm{Mg} / \text { year }\end{array}$} \\
\hline Incineration plant & - & \multicolumn{2}{|c|}{-} & $240,000 \mathrm{Mg} /$ year \\
\hline $\begin{array}{l}\text { Recovery of } \\
\text { building waste }\end{array}$ & $12,000 \mathrm{Mg} /$ year & \multicolumn{3}{|c|}{$30,000 \mathrm{Mg} /$ year } \\
\hline $\begin{array}{l}\text { Selective waste } \\
\text { collection }\end{array}$ & \multicolumn{4}{|c|}{ Sets of containers for selective waste collection - ultimately 750 sets ensuring collection of $9,000 \mathrm{Mg} / \mathrm{year}, 9$ within the city } \\
\hline $\begin{array}{l}\text { Export of municipal } \\
\text { waste to other region }\end{array}$ & \multicolumn{4}{|c|}{$\begin{array}{l}\text { Export of municipal waste reaching } 70,000 \mathrm{Mg} / \mathrm{year} \text { out of the system, and import of municipal waste into the system at the } \\
\text { level of ca. } 7000 \mathrm{Mg} / \text { year until the end of } 2012\end{array}$} \\
\hline \multicolumn{5}{|c|}{ Comments } \\
\hline $\begin{array}{l}\text { Two-container } \\
\text { municipal waste } \\
\text { collection system }\end{array}$ & - & $\begin{array}{l}\text { cover approximately } \\
45 \% \text { residents in the } \\
\text { City of Cracow }\end{array}$ & $\begin{array}{l}\text { cover all residents in the } \\
\text { City of Cracow }\end{array}$ & $\begin{array}{l}\text { cover approximately } 12 \% \\
\text { residents in the City } \\
\text { of Cracow }\end{array}$ \\
\hline
\end{tabular}

$$
L_{\alpha}\left(S_{n}\right)=\sum_{m=1}^{M} w_{m}^{\alpha} \cdot\left(x_{m}^{\prime}-r_{N M}^{\prime}\right)^{\alpha}
$$

while the best strategy is selected according to the following rule:

$$
S_{j}=\dot{S} \Leftrightarrow L_{\alpha}\left(S_{j}\right)=\min L_{\alpha}\left(S_{n}\right)_{; n=1,2, \cdots}
$$

where: $L_{\alpha}\left(S_{n}\right)$-measure of the distance between examined strategy sn and ideal point; $S_{n}$-selected strategy; $w_{m}$-weight coefficient for criterion $\mathrm{m} ; x_{m}^{\prime}-\mathrm{mth}$ coordinate of utopian point; $r_{N M}^{\prime}$-normalised criterion value; $M$ - number of criteria; $\alpha$ - power exponent measuring deviation of strategy from utopian point $X$ - In - practice 1,2 and $\infty$ is taken.

The method allows weigh criteria, and assign weights to them, besides attributed values measuring achievement of goals $[11,16,19,20]$. The outcome of completed computations includes ordering of strategies for waste management system solutions in the region, depending on assumed weights of criteria or weights of individual groups of criteria. Final decision concerning selection of shape and function for waste management system in the region shall be made by decision-maker, who may assume specific weights of criteria and accept resultant solution, depending on preferences and needs of the region. Accepted waste management system solution shall be verified after few years of its functioning and evaluated once more $[11,12,17,19]$.

\section{Results of Multi-criteria Analysis for the Selection of Waste Scenarios}

For computational purposes it is necessary to adopt validity hierarchy of individual criteria, determining priorities for decision-making process participants $[8,10,11,16]$. In case 1 weight 1 was assigned to each criterion. In the second case, minimisation and recovery criteria were given weight 5 , while all other criteria-weight 1 . Whereas, in the last line minimisation and recovery criteria and social and political criteria were given weight 5 , and economic criteria-weight 1 . Analysis results are shown in Table 4.

This method allows further weighing of criteria by using power exponent $\alpha$ in the formula. This exponent allows to additionally weighing all deviations from ideal point, proportionally to their size. The higher value $\alpha$ the more important are high strategy deviations from ideal point. Individual computational cases taking into account various values of coefficient $\alpha$ are shown in three different columns in Table 4. Ordering of strategies for waste management system in Cracow is the outcome of the analysis, presented in the last column in Table 4. 
Table 2. Technical social and political criteria for identified scenarios of waste management in Cracow, after 2007.

\begin{tabular}{|c|c|c|c|c|c|c|}
\hline & \multirow{2}{*}{ Criterion } & \multirow{2}{*}{$\begin{array}{l}\text { Limit specified in legal articles, } \\
\text { or best value }\end{array}$} & \multicolumn{4}{|c|}{ Scenario [thousand $\mathrm{Mg}$ ] } \\
\hline & & & S0 & S1 & S2 & S3 \\
\hline K1 & $\begin{array}{l}\text { Reduction in the volume of dumped } \\
\text { municipal waste }\end{array}$ & $\begin{array}{l}44,000 \mathrm{Mg} \text { until the end of } 2014 \text { according } \\
\text { to Voivodship Waste Management Plan }\end{array}$ & $\begin{array}{c}52 \\
(>100 \%)\end{array}$ & $\begin{array}{c}95.3 \\
(>100 \%)^{b}\end{array}$ & $\begin{array}{c}101.3 \\
(>100 \%)^{\mathrm{b}}\end{array}$ & $\begin{array}{c}243.5 \\
(>100 \%)^{\mathrm{b}}\end{array}$ \\
\hline \multirow{3}{*}{ K2 } & \multirow{3}{*}{$\begin{array}{l}\text { Reduction in the volume of dumped } \\
\text { biodegradable municipal wastes (requirement } \\
\text { of the Act on Wastes and 99/31/EC of 2011) }\end{array}$} & $\begin{array}{l}\text { until the end of } 2010 \\
65,600 \mathrm{Mg}\end{array}$ & $\begin{array}{c}28.2 \\
(43.1 \%)\end{array}$ & $\begin{array}{c}33.3 \\
(50.8 \%)\end{array}$ & $\begin{array}{c}52.0 \\
(79.3 \%)\end{array}$ & $\begin{array}{c}34.6 \\
(52.7 \%)\end{array}$ \\
\hline & & $\begin{array}{l}\text { until the end of } 2013 \\
97,500 \mathrm{Mg}\end{array}$ & $\begin{array}{c}29.3 \\
(30.0 \%)\end{array}$ & $\begin{array}{c}102.6 \\
(>100 \%)\end{array}$ & $\begin{array}{c}120.1 \\
(>100 \%)\end{array}$ & $\begin{array}{c}154.2 \\
(>100 \%)\end{array}$ \\
\hline & & $\begin{array}{l}\text { until the end of } 2020 \\
123,700 \mathrm{Mg}\end{array}$ & $\begin{array}{c}29.3 \\
(23.7 \%)\end{array}$ & $\begin{array}{l}126.6 \\
(>100 \%)\end{array}$ & $\begin{array}{l}131.9 \\
(>100 \%)\end{array}$ & $\begin{array}{l}162.9 \\
(>100 \%)\end{array}$ \\
\hline K3 & Materials recovery & $89,100 \mathrm{Mg}$ & $\begin{array}{c}38.4 \\
(43.1 \%)\end{array}$ & $\begin{array}{c}72.9 \\
(81.8 \%)\end{array}$ & $\begin{array}{c}89.1 \\
(100 \%)\end{array}$ & $\begin{array}{c}51.6 \\
(57.9 \%)\end{array}$ \\
\hline K4 & Energy recovery & $97.5 \mathrm{GWh}$ & $\begin{array}{l}8 \mathrm{GWh} \\
(8.2 \%)\end{array}$ & $\begin{array}{l}4 \mathrm{GWh} \\
(4.1 \%)\end{array}$ & $\begin{array}{l}4 \mathrm{GWh} \\
(4.1 \%)\end{array}$ & $\begin{array}{l}97.5 \mathrm{GWh} \\
(100 \%)\end{array}$ \\
\hline K5 & Landfill site operation time & counted since 2005 & $\begin{array}{l}12 \text { years } \\
(31.6 \%)\end{array}$ & $\begin{array}{l}13 \text { years } \\
(34.2 \%)\end{array}$ & $\begin{array}{l}15 \text { years } \\
(39.5 \%)\end{array}$ & $\begin{array}{c}38 \text { years } \\
(100 \%)\end{array}$ \\
\hline K6 & $\begin{array}{c}\text { Compliance with directions indicated by the } \\
\text { KPGO and WPGO }\end{array}$ & $0 / 1$ & 0 & 1 & 1 & 1 \\
\hline K7 & Compliance with the EU directives & $0 / 1$ & 0 & 1 & 1 & 1 \\
\hline K8 & $\begin{array}{l}\text { Regional and prospective character of } \\
\text { the solution }\end{array}$ & $0 / 1$ & 0 & 0 & 0 & 1 \\
\hline K9 & Social acceptance & 0.86 & 0.4 & 0.83 & 0.83 & 0.86 \\
\hline
\end{tabular}

Table 3. Economic criterion for identified scenarios of waste management in Cracow, after 2007 [PLN].

\begin{tabular}{|c|c|c|c|c|c|c|c|c|c|c|c|c|c|c|}
\hline Scenario & 2007 & 2008 & 2009 & 2010 & 2011 & 2012 & 2013 & 2014 & 2015 & 2016 & 2017 & 2018 & 2019 & 2020 \\
\hline \multicolumn{15}{|c|}{ Comparison of monthly charges per 1 resident in individual scenarios } \\
\hline $\begin{array}{l}\text { S0 without } \\
\text { subsidy }\end{array}$ & 6.72 & 8.06 & 9.32 & 9.73 & 10.18 & 10.64 & 12.07 & 12.56 & 13.08 & 14.00 & 17.41 & 18.17 & 18.85 & 19.61 \\
\hline $\begin{array}{l}\text { S1 without } \\
\text { subsidy }\end{array}$ & 6.77 & 9.16 & 10.85 & 11.74 & 12.37 & 13.08 & 18.34 & 19.40 & 20.23 & 21.41 & 22.50 & 26.26 & 27.18 & 28.38 \\
\hline $\begin{array}{l}\text { S2 without } \\
\text { subsidy }\end{array}$ & 6.77 & 9.51 & 11.28 & 12.33 & 13.17 & 13.95 & 17.97 & 19.27 & 20.53 & 21.89 & 23.07 & 27.20 & 28.70 & 30.15 \\
\hline $\begin{array}{l}\text { S3 without } \\
\text { subsidy }\end{array}$ & 6.69 & 8.38 & 9.99 & 10.87 & 11.43 & 12.02 & 16.61 & 17.22 & 17.87 & 18.87 & 19.65 & 20.43 & 21.17 & 22.05 \\
\hline $\begin{array}{l}\text { S3 with } \\
\text { subsidy }\end{array}$ & 6.46 & 8.15 & 9.66 & 10.37 & 10.91 & 11.48 & 13.88 & 14.47 & 15.08 & 16.01 & 16.77 & 17.53 & 18.23 & 19.07 \\
\hline \multicolumn{15}{|c|}{ Comparison of management (disposal) costs for $1 \mathrm{Mg}$ of wastes in individual scenarios $[P L N / M g]$} \\
\hline $\begin{array}{l}\text { S0 without } \\
\text { subsidy }\end{array}$ & 306 & 366 & 422 & 440 & 459 & 478 & 540 & 560 & 580 & 618 & 764 & 793 & 817 & 844 \\
\hline $\begin{array}{l}\text { S1 without } \\
\text { subsidy }\end{array}$ & 308 & 416 & 492 & 531 & 558 & 588 & 821 & 865 & 898 & 945 & 987 & 1146 & 1178 & 1221 \\
\hline $\begin{array}{l}\text { S2 without } \\
\text { subsidy }\end{array}$ & 308 & 432 & 511 & 557 & 594 & 627 & 804 & 859 & 911 & 966 & 1013 & 1187 & 1244 & 1297 \\
\hline $\begin{array}{l}\text { S3 without } \\
\text { subsidy }\end{array}$ & 305 & 381 & 453 & 492 & 515 & 540 & 743 & 767 & 793 & 833 & 863 & 891 & 917 & 948 \\
\hline $\begin{array}{l}\text { S3 with } \\
\text { subsidy }\end{array}$ & 294 & 370 & 438 & 469 & 492 & 516 & 621 & 645 & 669 & 707 & 736 & 764 & 790 & 820 \\
\hline
\end{tabular}

Explanations: option without subsidy — in which the Municipality does not use opportunities to obtain subsidies from the European funds to purchase permanent assets; option with subsidy — when the Municipality uses subsidies of this sort. 
Table 4. Multi-criteria analysis results for identified scenarios of waste management system for the City of Cracow after 2007.

\begin{tabular}{|c|c|c|c|}
\hline \multirow{2}{*}{$\begin{array}{l}\text { Validity hierarchy for the following criteria: minimisation and recovery } \\
\text { of wastes:social and political:economic }\end{array}$} & \multicolumn{3}{|c|}{ Ordering of strategies } \\
\hline & $\alpha=1$ & $\alpha=2$ & $\alpha=\infty$ \\
\hline $1: 1: 1$ & $\mathrm{~s}^{3)} \rightarrow \mathrm{s} 2 \rightarrow \mathrm{s} 1 \rightarrow \mathrm{s} 0$ & $\mathrm{~s}^{3}{ }^{\mathrm{a}} \rightarrow \mathrm{s} 1 \rightarrow \mathrm{s} 2 \rightarrow \mathrm{s} 0$ & $\mathrm{~s} 3^{\mathrm{a})} \rightarrow \mathrm{s} 2 \rightarrow \mathrm{s} 1 \rightarrow \mathrm{s} 0$ \\
\hline $5: 1: 1$ & $\mathrm{~s}^{\left.3^{\mathrm{a}}\right)} \rightarrow \mathrm{s} 1 \rightarrow \mathrm{s} 1 \rightarrow \mathrm{s} 0$ & $\mathrm{~s}^{3}{ }^{\mathrm{a})} \rightarrow \mathrm{s} 2 \rightarrow \mathrm{s} 1 \rightarrow \mathrm{s} 0$ & $\mathrm{~s}^{3)}$ \\
\hline $10: 1: 1$ & $\mathrm{~s}^{3}{ }^{\mathrm{a})} \rightarrow \mathrm{s} 2 \rightarrow \mathrm{s} 1 \rightarrow \mathrm{s} 0$ & $\mathrm{~s} 3^{\text {a) }} \rightarrow \mathrm{s} 2 \rightarrow \mathrm{s} 1 \rightarrow \mathrm{s} 0$ & $s 3^{a)}$ \\
\hline $1: 5: 1$ & $\mathrm{~s}^{3}{ }^{\mathrm{a}} \rightarrow \mathrm{s} 2 \rightarrow \mathrm{s} 1 \rightarrow \mathrm{s} 0$ & $\mathrm{~s} 3^{\mathrm{a})} \rightarrow \mathrm{s} 1 \rightarrow \mathrm{s} 2 \rightarrow \mathrm{s} 0$ & $53^{\text {a) }}$ \\
\hline $1: 10: 1$ & $\mathrm{~s}^{3}{ }^{\mathrm{a}} \rightarrow \mathrm{s} 2 \rightarrow \mathrm{s} 1 \rightarrow \mathrm{s} 0$ & $\mathrm{~s} 3^{\mathrm{a})} \rightarrow \mathrm{s} 1 \rightarrow \mathrm{s} 2 \rightarrow \mathrm{s} 0$ & $53^{\mathrm{a})}$ \\
\hline $1: 15: 1$ & $\mathrm{~s} 3^{\mathrm{a})} \rightarrow \mathrm{s} 2 \rightarrow \mathrm{s} 1 \rightarrow \mathrm{s} 0$ & $\mathrm{~s} 3^{\mathrm{a})} \rightarrow \mathrm{s} 1 \rightarrow \mathrm{s} 2 \rightarrow \mathrm{s} 0$ & $53^{\mathrm{a})}$ \\
\hline $1: 1: 2$ & $\mathrm{~s} 3^{\mathrm{a})} \rightarrow \mathrm{s} 1 \rightarrow \mathrm{s} 2 \rightarrow \mathrm{s} 0$ & $\mathrm{~s} 3^{\mathrm{a})} \rightarrow \mathrm{s} 0 \rightarrow \mathrm{s} 1 \rightarrow \mathrm{s} 2$ & $s 3^{\mathrm{a})}$ \\
\hline $1: 1: 5$ & $\mathrm{~s} 3^{\mathrm{a})} \rightarrow \mathrm{s} 0 \rightarrow \mathrm{s} 1 \rightarrow \mathrm{s} 2$ & $\mathrm{~s} 3^{\mathrm{a})} \rightarrow \mathrm{s} 0 \rightarrow \mathrm{s} 1 \rightarrow \mathrm{s} 2$ & $\mathrm{~s} 3^{\mathrm{a})} \rightarrow \mathrm{s} 1 \rightarrow \mathrm{s} 0 \rightarrow \mathrm{s} 2$ \\
\hline $1: 1: 6$ & $\mathrm{~s} 3^{\mathrm{a})} \rightarrow \mathrm{s} 0 \rightarrow \mathrm{s} 1 \rightarrow \mathrm{s} 2$ & $\mathrm{~s} 3^{\mathrm{a})} \rightarrow \mathrm{s} 0 \rightarrow \mathrm{s} 1 \rightarrow \mathrm{s} 2$ & 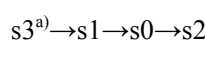 \\
\hline $1: 1: 10$ & $\mathrm{~s} 3^{\mathrm{a})} \rightarrow \mathrm{s} 0 \rightarrow \mathrm{s} 1 \rightarrow \mathrm{s} 2$ & $\mathrm{~s} 0^{\mathrm{a})} \rightarrow \mathrm{s} 3 \rightarrow \mathrm{s} 1 \rightarrow \mathrm{s} 2$ & $\mathrm{~s} 3^{\mathrm{a})} \rightarrow \mathrm{s} 1 \rightarrow \mathrm{s} 0 \rightarrow \mathrm{s} 2$ \\
\hline $5: 1: 5$ & $\mathrm{~s}^{3}{ }^{\mathrm{a})} \rightarrow \mathrm{s} 0 \rightarrow \mathrm{s} 2 \rightarrow \mathrm{s} 1$ & $\mathrm{~s} 3^{\mathrm{a})} \rightarrow \mathrm{s} 0 \rightarrow \mathrm{s} 1 \rightarrow \mathrm{s} 2$ & $s 3^{a)}$ \\
\hline $1: 5: 5$ & $\mathrm{~s} 3^{\mathrm{a})} \rightarrow \mathrm{s} 1 \rightarrow \mathrm{s} 2 \rightarrow \mathrm{s} 0$ & $\mathrm{~s}^{\mathrm{a})} \rightarrow \mathrm{s} 1 \rightarrow \mathrm{s} 2 \rightarrow \mathrm{s} 0$ & $s 3^{\mathrm{a})}$ \\
\hline $5: 5: 1$ & $\mathrm{~s} 3^{\mathrm{a})} \rightarrow \mathrm{s} 2 \rightarrow \mathrm{s} 1 \rightarrow \mathrm{s} 0$ & $\mathrm{~s} 3^{\mathrm{a})} \rightarrow \mathrm{s} 2 \rightarrow \mathrm{s} 3 \rightarrow \mathrm{s} 0$ & $s 3^{\text {a) }}$ \\
\hline
\end{tabular}

$\mathrm{S}_{\mathrm{n}}{ }^{\mathrm{a}}$ - acceptable strategy.

When examining multi-criteria analysis results, we may state that:

- In 39 computational cases, strategy S3 has been chosen most frequently (thermal processing of waste as an element of a complex waste management system) 38 times,

- In remaining 1 case, strategy S0 has been selected, which assumes implementation of an existing waste management system. It is chosen in the case when we take the economic criterion as the most important one (10 times more important than the other ones),

- Strategies S1 and S2 ("deep" segregation of waste and composting) haven't been chosen as the most favourable in any computational case,

- Decision-maker may assume some limitations in the strategy selection. In current computations, limitations of this sort have been taken as the so-called acceptability threshold calculated as follows:

$$
S_{n}^{a)}=0,1 * L_{\alpha}\left(s_{n}\right)_{\min }
$$

Acceptable strategies are indicated in Table 4 by " $a$ )", and they constitute a solution for decision-making task as the choice of strategy lying acceptably close to ideal point.

\section{Comparison of Multi-criteria Analysis Results for the System of Waste Management in Cracow Carried out in Years 2004 and 2000}

Programme [13] was developed in 2004. Based on its guidelines, individual waste management strategies were put to multi-criteria analysis. As in previous chapter, the same method of multi-criteria selection compromise programming was used in computations, whereas evaluating criteria were taken according to the above-mentioned plan. The five strategies were taken for the analysis (Table 5):

Scenario $S 1$ continuation of current state,

Scenario $S 2$ extension of selective collection system,

Scenario $S 3$ extended composting range,

Scenario $S 4$ thermal processing system for waste.

Scenario $S 5$ extension of segregation and processing of fractions collected in a two-container system.

Multi-criteria analysis for individual strategies of waste management in Cracow was carried out on the basis of the 10 criteria presented with the results for 
Table 5. Technical description of waste scenarios for the city of Cracow in 2004.

\begin{tabular}{|c|c|c|c|c|c|}
\hline Elements system & $S 1$ & $S 2$ & $S 3$ & $S 4$ & $S 5$ \\
\hline Landfill & \multicolumn{5}{|c|}{ approximately 2 million $\mathrm{m}^{3}$} \\
\hline Composting plant & $\begin{array}{c}6000 \\
\mathrm{Mg} / \text { year }\end{array}$ & $\begin{array}{l}\text { two installations, } \\
\text { each processing green } \\
\text { waste amounting to } \\
6000 \mathrm{Mg} / \text { year }\end{array}$ & $\begin{array}{l}\text { two in } \\
\text { gree } \\
\text { segr }\end{array}$ & $\begin{array}{l}\text { processing } \\
\text { l wet from } \\
\text { ounting to } \\
\text { /year }\end{array}$ & $\begin{array}{l}\text { two installations, each processing green waste amount- } \\
\text { ing to } 6000 \mathrm{Mg} / \text { year which may be extended up to } \\
12,000 \mathrm{Mg} / \text { year; and additionally extendable up to } \\
22,000 \mathrm{Mg} / \text { year for composting selectively collected wet } \\
\text { fraction and organic fraction separated in sorting plant }\end{array}$ \\
\hline Sorting plant & & 20,00 & $00 \mathrm{Mg} /$ & & $\begin{array}{l}20,000 \mathrm{Mg} / \text { year for one shift (according to scenario } \\
\text { guidelines designed for processing } 60,000 \mathrm{Mg} / \text { year), }\end{array}$ \\
\hline Incineration plant & \multicolumn{5}{|c|}{$200,000 \mathrm{Mg} /$ year } \\
\hline Large-size waste & \multicolumn{5}{|c|}{$12,000 \mathrm{Mg} /$ year } \\
\hline Selective waste collection & \multicolumn{5}{|c|}{ sets of containers for selective waste collection } \\
\hline $\begin{array}{l}\text { Export of municipal waste } \\
\text { to other region }\end{array}$ & \multicolumn{5}{|c|}{$80,000 \mathrm{Mg} /$ year } \\
\hline $\begin{array}{l}\text { Two-container municipal } \\
\text { waste collection system }\end{array}$ & \multicolumn{5}{|c|}{ single-family houses, "dry" and "wet" fractions } \\
\hline
\end{tabular}

every scenario in the Table 6. As before, the compromise programming method has been used in computations. When examining analysis results, we may state that:

- In 24 computational cases, strategy 4 has been chosen most frequently (thermal utilisation of waste as the system element) 17 times,

- In all other 7 cases, strategy 3 assuming extended composting range has been chosen. This strategy is selected in cases when assigned economic criterion weight is 10 ,

- As in previous chapter, decision-maker may assume some limitations in strategy selection. In these computations, limitations of this sort have been taken as the so-called acceptability threshold calculated as follows:

$$
S_{n}^{a)}=0.1 \cdot L_{\alpha}\left(S_{n}\right)_{\min }
$$

- Acceptable strategies are indicated in the table by " $a$ )", and they constitute a solution for decisionmaking task as the choice of strategy lying acceptably close to ideal point,

- Multi-criteria analysis is only a tool arranging waste management system strategies, whereas final decision concerning system selection is made by decisionmaker; in 2004, Scenario 5 was chosen for implementation by the City of Cracow in spite of the fact that in none of computational cases Strategy 5 was selected as the most favourable,

- Strategy 5 usually ranks second and in one case third,

- Strategy 5 is most frequently selected second, after Strategy 4 or 3 (chosen most often). Taking into account all criteria and assigning weights to them, we may say that if the choice is between Strategy 4 and 5 strategy 4 is selected, and if we are choosing between 3 and 5 Strategy 3 is preferred. In spite of this, Strategy 5 has been chosen for implementation.

Multi-criteria analysis for waste management system in Cracow was carried out three times: in 2000 [11], 2004 and 2007. Each time, few waste management scenarios were taken for analysis, and among them, current state analysis was always taken into account for comparison purposes as the starting scenario. Table 7 compares final results of all analyses.

\section{Summary and Conclusions}

- Selection of waste management strategy in the urban area is a difficult decision-making problem, which has to take into account different, often inconsistent goals and tasks, and social-economic and political interests.

- Defined measuring criteria allow establish quantitative and objectivised evaluation of waste management system functioning in technical, related to nature, economic and social aspects.

- On the basis of defined indicators and multi-criteria analysis it is possible to select most favourable scenario for waste management system in the urban area. The proposed methodology guarantees possibility to carry out quantitative, multidimensional, and at the same time objectivised evaluation of system solutions, which would replace intuitive or requiring experts opinions assessments used so far.

- In case of Cracow, the proposed method has been already employed three times, and this selection coincides with experts assessments; nevertheless decision-maker always makes final decision concerning 
Table 6. Criteria and decision matrix for waste management scenarios in Cracow in 2004.

\begin{tabular}{|c|c|c|c|c|c|}
\hline \multirow{2}{*}{ Criteria } & \multicolumn{5}{|c|}{ Scenario } \\
\hline & $S 1$ & $S 2$ & $S 3$ & $S 4$ & S5 \\
\hline crit. 1 -reduction in the volume of waste achieved in 2011, in [\%], & 21.1 & 45.9 & 46 & 100 & 80.5 \\
\hline crit. 2 -reduction of biodegradable waste - requirement of the EU directive, in [\%] & 30.7 & 46.9 & 65.3 & 100 & 83.1 \\
\hline crit. 3 -recovery of secondary materials, in [\%] & 37.7 & 83.7 & 83.7 & 91.2 & 100 \\
\hline crit. 4-energy recovery (in scenarios without incinerating plant, energy recovery from landfill site) [GJ] & 8.2 & 8.2 & 8.2 & 100 & 8,2 \\
\hline crit. 5-operation time of landfill site for processed waste, in [years] & 11 & 12 & 13 & 27 & 14 \\
\hline crit. 6-compliance with directions indicated by the KPGO [21] and WPGO [13] & 0 & 1 & 1 & 2 & 1 \\
\hline crit. 7-compliance with the EU directives & 0 & 0 & 1 & 2 & 1 \\
\hline crit. 8-regional and prospective character of the solution & 0 & 0 & 0 & 2 & 0 \\
\hline crit. 9-social acceptance & 1 & 4 & 4 & 2 & 4 \\
\hline crit. 10 - full monthly average financial charge per 1 resident [PLN/year] & 4.0 & 4.52 & 4.68 & 6.35 & 5.27 \\
\hline
\end{tabular}

Source: [22].

Table 7. Results of subsequent multi-criteria analyses for waste management system in Cracow.

\begin{tabular}{|c|c|c|c|c|}
\hline Year & $\begin{array}{l}\text { Number of waste } \\
\text { management scenarios }\end{array}$ & $\begin{array}{l}\text { Number of criteria } \\
\text { evaluating the scenarios }\end{array}$ & $\begin{array}{c}\text { Choice of scenario with incinerating } \\
\text { plant in relation to the number of } \\
\text { computed cases }\end{array}$ & Additional remarks \\
\hline 2004 & 5 & 10 & $17 / 24$ & $\begin{array}{l}\text { Additionally, the criteria take into account } \\
\text { biomass reduction. }\end{array}$ \\
\hline 2007 & 4 & 11 & $62 / 63$ & $\begin{array}{l}\text { Additionally, the criteria take into account } \\
\text { penalties administered by the EU for failing } \\
\text { to meet standards and the share of social } \\
\text { factor in decision-making process. }\end{array}$ \\
\hline
\end{tabular}

the system form.

- Very good effect was obtained after including community side into the decision-making process for selection of waste management system in the city. Community not only discusses analysis results, but it also is able to join in it by creating a waste management scenario or specifying evaluating criteria, to discuss computation results with experts, and to assign weights to the evaluating criteria.

- According to environment management requirements, the proposed methodology allows carry out system evaluation systematically, even in case of change in the purpose or determinants in the city. This method may be employed in continuous planning of a technical system implementing waste handling strategy, which has been shown on the example of Cracow.

\section{REFERENCES}

[1] Local Government Act, "The Act on Waste of April 27, 2001," Ministry of the Environment, Warszawa, 2001.
[2] Z. Kowalski and J. Kulczycka, "Cleaner Production as a Basic Element for the Sustainable Development Strategy," Polish Journal of Chemical Technology, Vol. 4, 2004, pp. 35-40.

[3] J. Kulczycka (Ed.), "Principles for Municipal Waste Management in Poland and Selected European Regions Best Practices," IGSMiE PAN, Cracow, 2007.

[4] J. Kulczycka and Z. Kowalski, "Principles of Municipal Waste Management in Poland and Selected Region of Europe," Polish Journal of Chemical Technology, Vol. 10, No. 4, 2008, pp. 28-33. doi:10.2478/v10026-008-0043-1

[5] J. Kulczycka, Z. Kowalski and M. Cholewa, "Municipal Waste Management in Polish National and Local Plans," Technology Magazine, Cracow University of Technology, Vol. 2, 2008, pp. 13-24.

[6] R. Perman, Y. Ma and J. McGilvray, "Natural Resource \& Environmental Economics," Longman, London, New York, 1996.

[7] E. den Boer, A. Jędrczak, Z. Kowalski, J. Kulczycka and R. Szpadt, "A Review of Municipal Solid Waste Composition and Quantities in Poland," Waste Management, Vol. 30, No. 3, 2010, pp. 369-377. 
doi:10.1016/j.wasman.2009.09.018

[8] A. Generowicz and T. Stypka, "The Examples of Application of Multi-criteria Analysis in Regional System of Waste Managing," In: 6th International Forum of Waste Managing re: "Efficiency of Waste Managing", Poznan/Lichen Stary, 2005.

[9] Local Government Act, "The Małopolska Region Development Strategy for 2007-2013," Marshal of the Malopolska Region, Cracow, 2006.

[10] M. Garfì, S. Tondelli and A. Bonoli, "Multi-criteria Decision Analysis for Waste Management in Saharawi Refugee Camps," Waste Management, Vol. 29, No. 10, 2009, pp. 2729-2739. doi:10.1016/j.wasman.2009.05.019

[11] A. Generowicz, "Evaluation Indexes for Multi-criteria Selection of Solution for Regional Waste Management System," Doctoral Dissertation, Cracow University of Technology, Cracow, 2001.

[12] J. Hokkanen and P. Salminen, "Choosing a Solid Waste Management System Using Multi-criteria Decision Analysis," European Journal of Operational Research, Vol. 98, No. 1, 1997, pp. 19-36. doi:10.1016/0377-2217(95)00325-8

[13] Local Government Act, “Ocena Strategiczna Systemu Gospodarki Odpadami Miasta Krakowa wraz z Wyborem Wariantów Lokalizacji Zakładu Termicznego Przekształcania Odpadów Komunalnych,” Cracow, 2007.

[14] C. Rosik-Dulewska, "Waste Management Rudiments," PWN, Warszawa, 2007.

[15] P. Aragonés-Beltrána, J. A. Mendoza-Rocab, A. Bes-Piáa, M. García-Melónb and E. Parra-Ruizb, "Application of Multi-criteria Decision Analysis to Jar-Test Results for Chemicals Selection in the Physicalchemical Treatment of Textile Wastewater," Journal of Hazardous Materials, Vol. 164, No. 1, 2009, pp. 288-295. doi:10.1016/j.jhazmat.2008.08.046

[16] E. Erkut, A. Karagiannidis, G. Perkoulidis and S. A. Tjandra, "A Multi-criteria Facility Location Model for Municipal Solid Waste Management in North Greece," European Journal of Operational Research, Vol. 187, No. 3, 2008, pp. 1402-1421. doi:10.1016/j.ejor.2006.09.021

[17] J. Górniak-Zimroz, "Using Decision-Making Support Systems in Waste Management," Scientific Works of Mining Institute, Wrocław University of Technology, Vol. 118, 2007.

[18] I. Linkov, F. K. Satterstrom, G. Kiker, C. Batchelor, T. Bridges and E. Ferguson, "From Comparative Risk Assessment to Multi-criteria Decision Analysis and Adaptive Management: Recent Developments and Applications," Environment International, Vol. 32, No. 8, 2006, pp. 1072-1093. doi:10.1016/j.envint.2006.06.013

[19] N. Roussat, Ch. Dujet and J. Méhu, "Choosing a Sustainable Demolition Waste Management Strategy Using Multi-criteria Decision Analysis," Waste Management, Vol. 29, 2009, p. 1220. doi:10.1016/j.wasman.2008.04.010

[20] A. J. Morrissey and J. Browne, "Waste Management Models and Their Application to Sustainable Waste Management," Waste Management, Vol. 24, No. 3, 2004, pp. 297-308. doi:10.1016/j.wasman.2003.09.005

[21] Local Government Act, "National Waste Management Plan 2010," Ministry of the Environment, Warszawa, 2006.

[22] A. Generowicz and Z. Grabowski, "Multicriterial Analysis as a Help Tool in Choice of Solution of Regional Waste Management System Based on Cracov Key Study," In: 4-th International Waste Forum, Efficiency of Waste Management, Poznan, 29 May-1 June 2005. 